\title{
Historical Ancient Mountain Cults Called "Philashaphim"
}

\author{
Charles Ogundu Nnaji \\ Department of Philosophy and Religion, University of Abuja, Abuja, Nigeria \\ Email: economos34@yahoo.com
}

Received 28 September 2015; accepted 18 March 2016; published 21 March 2016

Copyright @ 2016 by author and Scientific Research Publishing Inc.

This work is licensed under the Creative Commons Attribution International License (CC BY). http://creativecommons.org/licenses/by/4.0/

(c) (7) Open Access

\begin{abstract}
The study simply pointed out that what Balaam did in Numbers 22:41, Numbers 23:1-16, was consultation of gods at prophetic (Sophian) ancient mountain cults. They were called Philasaphim or occultic (i.e. secret) consultations of extraordinary wonder working powers, Hebrew "Niphilaosophiru", Judges 6:13, Job 5:9, Psalm 75:1, i.e. the inexplicable or numbers uncountable. The study employed classist textual geographical maps illustrations methodology in presenting the occultic secrets Assemblies, Hebrew Pilosopaot in Orphic-Sopherim (Teachers of mysteries; Woodrow, 1969) as seen in Ecclesiastes 12:11 called Masters of Assemblies, however what this study found out were the Casdimah, magi or Ashaphs called the "Baalisophot" Hebrew "Phylasophu" leaders of mountain (Baal or Phaal) Ezekiel 13:18 i.e. secret cults of the sophis (serpent, Mathew 10:16 wisdom of the Kedemar and the Chaldean-Casaphis; Isaiah 2:6).
\end{abstract}

\section{Keywords}

Historical, Ancient, Mountain, Geography, Cult, Philasaphim

\section{Points to Note in This Study}

1) To find out in Hebrew is "Philu” Jonah 1:7, 1 Samuel 14:42, Exodus 28:6, "Ephili” (Ephod-spiritual) from the extraordinary or the "Saphir"; casting lots with magic stones to find out, i.e. sorcery, Thumim and Urim, 1 Samuel 14:42, Jonah 1:7, Hebrew "Sophan”, Greek "Psephon”, i.e. magic stones. The "Philasaphir”, i.e. "Philosophot" occultic) sophot; secret; Exodus 7:11 and 22) Daniel 4:9.

2) The oracular Delphili at the Aegean Mount Parnassus in ancient Greece were models of the Philistine "Baalzebub” (2 Kings 1:1-3, Exodus 14:1) see Ezekiel 6:1-6 (Israel’s occultic mountains), Daniel 11:29, Nehemiah 11:21, "Ophel” (Temple Hill) Acts 17:22, the Greek "Areon-pagon” (Hebrew “Ophel Sophaqu”, i.e. pagan city councils (Hills of pagans of mars) and pagan gods. 
3) Compare Numbers 11:4 Hebrew "Saphilsaphia” Aramaic "saphsaph”, i.e. Gentile, corrupted, mixture, additions foreigners or pagans Isaiah 2:6. Philisti-sophiku or phalasaphaqu, Hosea 7:1, i.e. foreign gods are falsehoods; see Colossians 2:8).

\section{General Introduction to the Study}

The historical geography of ancient mountain cults called "Philasaphim" simply means that the history of ancient religions was consulting supernatural powers or gods believed to reside on mountain tops (Losipha, Nehemiah 11:21). Hence, Phoenician "Balaam sophim" or Aramaic "Phalisaphan" (mountain cults that Baalzebub) were ancient philosophim, i.e. mountains of prophecy, like the oracle of Delphi in Greece (New \& Philips, 1953) Elijah, 1 Kings 19:8, 2 Kings 1:1-3, Nehemiah 11:21, Nehemiah 3:26-27 (Ophel-Temple Hill)Micah 4:8 “Ophel” translated Jerusalem built on the Ophel Sophi, i.e. stronghold of God; also called Sion or Zion (the mountain of God Isaiah 14:12-16) 2 Chronicles 3:1 "Solomon's Temple was built on the sacred Mountain of "Moriah". Also note Elijah on Mount Carmel. Jesus always prayed on mountains. Then, Mount Sinai or Mount Horeb, the greatest mountain of God (Exodus 19:20-23) etc. Simply put, the word philosophy was transliterated from the Phoenician mountain cult of "Baalzephon" (Exodus 14:1 or Baalzebub) near Egypt, written as "Baali-sophot" in Ecclesiastes 12:11 (in Aramaic-Hebrew, it is "Phalisophu") then to the Greek "Philosophon" (see Revelations 9:11) which means the "Phallu" or male leaders of the occult (or KJV Masters of Assemblies) i.e. Phalushaphat called "Pilosophaot" (Pilos-magicin Ezekiel 13:18-20 mountain cults; use the KJV on the Ephramite dialect that transliterated the Cashdimah tongue "kisit" from Casaph (i.e. magic) or the Aphialashaphir of Daniel 4:9 (i.e. the chief magician or the extraordinary). Please note that what Acts 17:22 called "Areopagus" (Greek "Areon-pagon" in Hebrew is "Ophelsophaqu”, i.e. pagan hills of mars or council of the philashaphim, or Athenian leaders) Aland and Newman, 1983, (Greek Areon is Hill or height; in Hebrew it is sacred Ophel; Nehemiah 11:21).

\section{Intention and Significance of This Paper}

This research study intends to show that Colossians 2:8 condemnation of philosophia was not out of the ordinary rather that it signifies that ancient philosophy was occultic (sophot) finding out (Hebrew "Philu") through magic or Aphialashaphir (Daniel 4:9), i.e. chief magician or the extraordinary which Apostle Paul condemned in Colossians 2;8 as outdated elemental spirits, customs and traditions whose wisdom come from occultic mediums of the Baala or Pallas Athene (Hebrew "Phalasaphya" the serpent spirit of divination). Hebrew Old Testament, 2005, Zondervan, 1990.

\section{Major Objectives of This Study}

1) To historically and geographically prove that "wisdom" (Ashaphim or sophis; i.e. the serpent spirit of divination or inquiry come from the East (Isaiah 2:6) (Aland \& Newman, 1983: p. 157) 2 Peter 1:16 "cleverly crafted" (Hebrew "Sophis") and consulting the dead "saphilsaphim" (Isaiah 8:19) which originated over 3000 years ago before Greekphilosophyfrom the near (far) east of the Chaldeans (i.e. Babylonian "Baal”, Hebrew "Phaal" (i.e. human or manmade gods).

\section{Very Important}

2) Hence, in Daniel 4:9 the Babylonian king Nebuchadnezzar clearly called Daniel “Aphialasaphir” (i.e. chief magician, i.e. the extraordinary or chief priest) being a transliteration from the Sumerian "Beltesazzar" or the Chaldean.Philistine "Baalzeboul" (2 Kings 1:1-3) or Baalzephon, Exodus 14:1 (i.e. consulting the mountain cults and chief priests of Baal on the erroneous belief that Daniel was using occultic powers like the "Baalas-oph" (Phalasoph; witch of Endor, 1 Samuel 28:1-11) Zondervan-Goodrich, 1990, Hebrew Old Testament, 2005, BDB, 2007 etc. (Please see above for transliteration rules).

\section{Also Very Important}

3) That the Phoenician "Zephaniah" and "Zophim" (Numbers 23:14) are Hebrew/Greek "Sophon" or "Sophonias" whichactually means "Hidden" (translated as treasure or hidden treasures) from another Phoenician "Sophot" (i.e. occult) or spiritual; /mysery assemblies (Ecclesiastes 12:11).

4) And to use readable ancient classist maps to prove these above hypothesis-objectives (i.e. claims). 


\section{Language Extracts and Facts of This Study}

a) Phoenician (Pilosopaot or Philosophot i.e. Philistia, 2 Kings 1:1-3 or Ezekiel 13:18-20), Isaiah 2:6, i.e. find out from the Baal, or Phaali (the occult) see Ecclesiastes 12:11 or KJV: Ezekiel 13:18-20 Pillows; Philos: magic: Isaiah 2:6, 1 Samuel 14:42, Isaiah 8:19 "Saphilsaphim" consult the dead; then the Hebrew "Philu” (cast lots, to find out) Jonah 1:5-7, 1 Samuel 14:42, Nehemiah 11:1 etc.

b) "Yavan Sephir": Greece is a rough goat (Daniel 8:5 and 21) i.e. foolish or human wisdom (1 Corinthians 1:18-20).

c) Daniel 8:5 and 21 called Greece “Goat” Hebrew "Sephir”, Phoenician "Zephir” i.e. they think they know, pagan is Greek "Ellenes” i.e. philosophy was consulting the "Delphilisophis" (i.e. serpent-pytha cult) to find out (Hebrew “Philu”) mysteries (Orphic-Sophaot: Daniel 13:18-20' veiled or hidden or secret crafts) these which used the Hebrew words above just the way it has been presented here. But once translation to English is carried out, those words unfortunately disappear.

\section{Please See the Following Extracts from the Study}

1) Jeremiah 46:19, Isaiah 19:13 “Egypt is Nophili, Phanisaphat” (i.e. Egypt is misled by her family or tribal leaders) Use KJV or the original-Hebrew Old Testament.

2) Jeremiah 46:21, Egypt is "Yaphia-saphiya” (beautiful but false; Colossians 2:4, Colossians 2:8), Hebrew Old Testament, 2005.

3) Hebrew "Phalasaphar”, Arabic “falsafa”, English “falsify” (2 Kings 16:9-10, "Phileseph” is occultic and destructive”, i.e., Pileser, of Assyria).

4) Jeremiah 46:19, Isaiah 19:13 “Egypt is Nophili, Phanisaphat” (i.e. Egypt is misled by her family or tribal leaders) Use KJV or the original.

5) Jeremiah 46:21, "Egypt is “Yaphia-saphiya” (beautiful but false; Colossians 2:4, Colossians 2:8).

\section{Classist Facts}

1) Hebrew "Loshaphati” (to practice customs and traditions; Ezekiel 23:45) 2 Kings 17:33-34, Colossians 2:8 (Hebrew Old Testament, 2005: pp. 712-714). Repeated in Colossians 2:8, that Philosophia is teaching human customs and traditions (Greek "Paradosin”) claiming they are visions from God. Colossians 2:18.

2) Philosophia (i.e. Colossians 2:8 teachers of outdated customs, traditions and ideas, Greek “Paradosin”), Hebrew "Yishaphati” (Ezekiel 24:45, 2 Kings 17:29-34) compare to Colossians 2:8-23.

3) Philosophia (Hebrew "Phi-Mi-Loshaphat" 2 Kings 17:33-34, "practicing customs and traditions, see outdated in the Hebrew "Phaal” (human or manmade) Greek "Phalaios or Phaulos" (Colossians 2:8-23). James 3:13-17 (v 16) human evils and excesses.

4) Casophi: Joel 3:5-6, "You carried away Jerusalem and her finest silver, ideas, customs and traditions to Greece” (outdated "Phaali, Phalasu or idolatry").

5) Jewish “Phila” (Exodus 33:16), i.e. separated or spiritual (Greek “Orphic”, i.e. mysterious) Woodrow, 1969, pp 70-71: Chambers Goodrich (1996) Plato is Orohic or Orphila (i.e. abstract or esoteric).

6) Greece is a "Sephir" (Rough Goat) Daniel 8:5 and 21, 1 Corinthians 1:18-26, i.e. Phaulos, foolish or human wisdom (James 3:13-17 etc).

7) 2 Kings 17:30-32 "Philosophar”, "Philasur” or "Phalasupha” (Baabel Assur) which means that Phileso (Pileser) and Assyria is worthless divination and of destructive words (Supha) Nehemiah 3:4, Nehemiah 1:3, sorcery (Phala-asuph or Pileser, i.e. Philesur; see 2 Kings 16:7-18 (1-18). See Hebrew Old Testament, 2005.

8) Go to Jeremiah 6:26 and Micah 1:10-11, see again the Hebrew "Philasaphir" (worthless dust) in 2 Chronicles 15:16; NIV is repulsive; in Good news it is obscene.

\section{Study by Words}

a) They travelled from Ionia of Asia Minor to Kedemar and Casdimah through Jerusalem and Egypt to learn "Vilasaphim", Mecasaphim, Cosophim and the Ceseph; Isaiah 2:6, Deuteronomy 18:9-14, BDB, p 357) see the Herem (sun) Heres (clever then to Heraclitus, of the Tophetsophet fire philosophy; Jeremiah 19:5-6) Hebrew "Tophilaserphi” = fire divination) then to the falsely invented, shrewd, p 361, Heresh (magic) secretly 
devised stories, “sophis” (2 Peter 1:16).

b) Psalm 40:15 Hebrew "Philosophata" to Philosophot (Baalisophot) to occultically mislead; 2 Chronicles 23:1 "Elishaphat" (God judges or leads). See Genesis 36:40 "Eluphiloshaphat”, family human and spiritual leaders of Esau; or pagans; compare to Colossians 2:8-23 or to destroy the human soul which Apostle Paul applied in Colossians 2:8, as Philosophia (sopheca; Genesis 9:6 to shed blood); i.e. misleading, occultic or spiritual (sophot) human (phelos) branches of many dangerously divisive Jewish opinions (soephim; 1 Kings 18:21) see Baalisoephim or Phalasaphaq, i.e. floating in-between many gods, or multiplicity of human teachings and many false opinions: Hosea 7:1 "Phalasaqer", Baalsoephe (Phaalisoephi), i.e. false mountain oracles such as Delphi in Greece) New and Philips, 1953: p. 96. See Numbers 23:14 "Balaamsophim" (Phalasophim; false prophet, Isaiah 56:10 etc).

c) The Chaldeans were also the Mecashaphim, i.e. magicians or astrologers (Daniel 2:2-27, Exodus 7:11, Daniel 3:8).

d) The Mecashaphim of Egypt as recorded in Exodus 7:11 clearly shows that Egyptian magic (Nophili: Jeremiah 46:19 or the Ashaphim or ancient wisdom) came from the East (i.e. Chaldea, Casdim, Wasdim or Wisdom, Daniel 3:8, Daniel 2:2, Mathew 2:1-3, i.e. Magi (Hebrew “Ashaphim”, or magic) or astrology, see Genesis 15:5 "Losopher or Philosapher" Job 5:9, i.e. uncountable or unsearchable. God asked Abraham in Genesis 15:5 "Losopher”, (Job 5:9) can you count the stars (Astrology) Job 5:9 “Niphilaosapher”, i.e. uncountable; or that which cannot be numbered or explained.

e) See Job 37:16, "Miphiloseaph”, that which floats; NIV.

\section{Geographical Etymology to the Ancient Phaulosophia; James 3:13-18}

1) The Hebrew "Phalisipha” (Evil doer: Job 34:32, see 2 Kings 10:23, "Phensopha” (Baal's ministers) to the Greek "Phaulosophia" (James 3:13-18, 15 and 16), human wisdom or wickedness; from the Chaldean "Baalisophot”, Baalcosophim to Phalisipha and "Philosopiku” (also Obadiah 1:20 "Sophad or Sepharad" to Philosophad", i.e. to mourn.

2) See the "Phalasu" for the Ionians or for Greek paganism (sophiku).

3) Isaiah 2:6, represents a classist-linguist body of facts completely lost once translation is done from original Biblical Hebrew and Greek to the English etc. 2 Kings 1:1-7 "Baalzebub" (also called "Baalzephon", Exodus 14:1 “i.e. Baal's Phaali (Hebrew "Ophel”, Nehemiah 11:21, Nehemiah 3:26-27) which means hills mountains or watchtower cults of the phalisipha (the devil; Job 34:32, 2 Kings 23;10-Baal or Phaali) and "phalisaphar", roll yourself in the dust) see "saphir" (i.e. beautiful but false) nations, which were also stages in the Semitic-Hebrew-Phoenician-Aramaic evolutions of the word "Philosophia". New and Philips (1953, pp. 52-53) displayed a map of ancient Aegean Attica with Athens as an island in the Aegean; to her south in the Mediterranean is Crete which BDB, 2007; 504, Zephaniah 2:5, Ezekiel 25:15-16 etc clearly states was the original home of the Philistines who left home to escape the invading Aeolians and Dorians before 1,800BC (New \& Philips, 1953) from Isaiah 2:6, we learn that magic came from the East Kedemar or Casdim including soothsaying from the Philisti (NCB, 2008).

4) Incidentally, the word "Philisti" is from "Phalasu" or Philasti-aphar i.e. worthless (Jeremiah 6:26, Micah 1:10-11 Hebrew Old Testament, 2005, "Saphir", beautiful but false) see (Pileser or Phileso) i.e. Palasti, which means "magic or pagan” (see KJV Ezekiel 13:18-20) Pillows is magic band, i.e. Taphili or Taphrot; to sow magic, see NIV etc.

5) Hence, 1 Samuel 17:26 and 36 Philistines are called "uncircumcised" i.e. falsehood, destroyers or sopheca; to shed blood: See Genesis 9:6, or pagans called sophiku; Isaiah 2:6) or Philistine "Baalzeboul" in 2 Kings 1:1-3; Hebrew Phalisipha: (Repulsive magicians: 2 Chronicles 15:16 NIV), Ezekiel 25:15. Philisti is ancient "Phaat" vengeance.

6) Look at Genesis 46:9, Genesis 35:22 Number 26:5-11 "Phaliu" (Palu) to Philis, i.e. uncircumcised or blind pagans, Mathew 15:14, 2 Corinthians 4:4, Greek “Tuphlosen”, i.e. blind guides or leaders (Philasaphat).

\section{A Big Research Question}

1) Who gave the Philistines (2 Kings 1:1-3) "fortune telling, the oracle, magic and the occult consulted and adopted (Bagash, Shaul or seer) by Israel and the ancient world? Ancient wisdom of consulting the occult, magic or witchcraft was "Phalsaphim” or "Saphilsaphim" (consulting the dead; Baalzeboul: 2 Kings 1:1-3, 
Isaiah 8:19, Deuteronomy 18:9-13 etc. (See the Hebrew Old Testament, 2005; 2 Kings 10:23, Phoenician-Hebrew "Phensopha” i.e to commit evil or to worship pagan gods (Phalasu) Ezekiel 8:10-17 (to commit evil) Job 34:32, "Phalisipha" (Evil).

2) Our introduction takes us to the following important citations from the ancient past. Ezekiel 8:16 "Mocking God's temple, they faced the East (Kedemah or Phaat-East side) to worship the sun god (Ishemesh or Herem or Heracli) Hebrew Old Testament, 2005”.

3) Isaiah 2:6: (a) magic and superstition (Malu from Phalu) is from Kedemah (the East) also called "Coshodim", or Casdim to wisdom, i.e. the Chaldeans or Astrologers (Hebrew "Asaphim”) BDB 2007, p 506, 80 (Necromancy), or Arabia; Jer 49:28.

4) Soothsaying or fortune telling came from "Philisti" (see 2 Kings 1:1-3), compare to Isaiah 2:6, Deuteronomy 18:9-14 etc.

Very Important

5) Mathew 2:1-16, the "magi” (Persian "magos”, Hebrew "Casoph” (Asaphi) translated astrologers, "saw the star of Jesus in the East" (Kedemah or Casdim or wisdim to wisdom).

6) The Chaldeans were also the Mecashaphim, i.e. magicians or astrologers (Daniel 2:2-27, Exodus 7:11).

7) The Mecashaphim, i.e. magicians recorded in Exodus 7:11 clearly shows that Egypt's magic (Ashaphim) or wisdom came from the East (i.e. Chaldea). See our data maps on "2.5.2".

8) See Daniel 2:1-27, Daniel 3:8 “Coshodim”, Casdin or Chaldea.

\section{Who Were the Casdim or Wasdim? Please See the Section Above; i.e. "A Big Research Question"}

a) Daniel 2:2, Daniel 3:8, Daniel 2:10-11 etc has the Hebrew "Casdim" (cosodim) is transliterated "Chaldeans" and translated as "Astrologers"; the Hebrews called them "Ashaphim" (magicians) see Matthew 2:1-16 "the magi" are translated as "wisemen” or astrologers”, BDB, 2007, p 505, which linked the Chaldeans to neighboring Babylonia, Assyria and Arabia.. In Biblical narratives, Chaldeans were good at interpreting dreams and reading the stars. (Mathew 2:1-3, Persian "magi” Hebrew Aramaic, “Ashaphim” (Greek "Pytho”). Daniel 2:2-27, Daniel 3:8. New and Philips (1953) pp 15-55, King Nebuchadnezzar around 602BC had annexed the Chaldean areas of Assyria subduing and enlisting them into his army which invaded and deported Jerusalem and Judah (587/586BC; Joel 3:5-6).

b) Boer (1980) presented a map of the ancient world (c1, 400BC) which showed Assyria looking like upper Mesopotamia (called "Chaldee”, while Babylonia located down south fell into lower Mesopotamia (called Shinar: Genesis 10:10 "Nimrod built Shinar (Babylon) then v 11-12 "Ashur" who built Nineveh (called Assyria) came from Shinar (Babylon). See Genesis 14:1 “Amraphel”, king of Shinar (Babylon) Hebrew Old Testament, 2005.

c) Thus, the Assyrians and Babylonians look very much the same ethnic stock (perhaps, Semitic; Genesis 10:1-12). Thus, the truth: 2 Kings 16:7-10 "Phalasur" (or Phileso, Pileser; i.e. king (Philah) of Assyria (Ashur; i.e. diviners) or outdated idolatry (Philis or Phalasu) see

d) Psa 58:2 "Tophalasun (corrupted, pagan) Psalm 50:16 "Ph-losapher” (evil or human teachings; spiritual falsehood; Hosea 7:1. Maer, 1988, like New and Philips (1953) noted that the historical ancient Abraham migrated from lower Mesopotamia (Ur and Shinar, i.e. Babylon; now Iraq) ibid, 1953.

\section{Statement of the Study's Hypothesia}

The study's upothesia (hypothesis) or statement of facts laid down or put forward for study or debate is that:

1) The word "philosophy" existed for over 2,000 years before Greek philosophy in the Chaldean "Mecashaphim", "Ashaphim" and "Baalcosophim” Nahum 3:4 (witchcraft) (2 Kings 1:1-3, "Baalzeboul and Baalzephon", Exodus 14:1: mountain (ophel) cults (sophaot) of Baal (Phaal) transliterated to the Hellenist Hebrew "Phalasophim” in Daniel 4:9 “Aphialasaphir" (i.e. chief priest or chief magician; Babylonian "Beltesazzar”: i.e. the gods (sephir or sipiri) dwells (Shecen) in you (Phalasu-flesh) Hebrew Old Testament, 2005.

2) That the geographical history of ancient wisdom (cesophim or Ashaphim: i.e. consulting the dead for information (Hebrew Aramaic "saphilsaphim", Isaiah 8:19) clearly indicates (without doubt) that travelling and wisdom seeking Ionians (outside Athens and Greece i.e. Asia Minor people of Lud) got the Hebrew "Phalasapha" (Arabic "falsafa"; English "falsify") from Asia Minor and the Kedemah (East: Mesopotamia) and 
Nophist (Egyptian or Memphis Jews; Jeremiah 46:19, Isaiah 19:13) who described "Chaldean”, Egyptian and Yavanian mountain cults of inquiry as "Phalisaphar" (Job 34:32) that was the occult or evil of obtaining information from manmade gods "Phalisaphar" (Isaiah 41:24 (1-25) etc). Ezekiel 13:18-20 or of the dead "Saphilsaphim”, Isaiah 8:19 etc.

3) To help prove the above, hypothetical questions (i.e. still under study) note that Asia Minor, i.e. (Ionian) Heraclitus, Pythagoras, Thales, Anaximander, Anaximenes (including Athenian Plato etc) all travelled to Egypt (Nophili: Jer 49:13, 46:19 KJV) and the East (Asianos Ashapha or Kedemah) to obtain wisdom (i.e. Ashaphim) see Isaiah 2:6, Daniel 2:2-10; Daniel 3:8 i.e. Chaldeans or Astrologers, see Mathew 2:1-16 “magi”, from the East, i.e. ancient wisdom called “Ashaphim” in Aramaic-Hebrew: BDB, 2007, pp 80, 506 etc (Deuteronomy 18:9-14) or saphilsaphim (Isaiah 8:19) i.e. consulting spirits, gods and the dead (sophadu; 1 Samuel 28:3-9) i.e. that fortune telling, came from the East and from Philistia (Isaiah 2:6).

4) The Hebrew "Philosophikuu”, in Isaiah 2:6 means “pagans or the uncircumcised, i.e. evil”, Job 34:32 “Phalisipha”.

\section{Additions to the Study's Hypotheses Textual Citations}

See 1 Samuel 28:3-11 "Baalas-Ob" (Phalasoph) i.e. the witch of Endor: Hebrew Old Testament, 2005; Exodus 22:17-18, Hebrew "Cesephi or Cosophim" 8 Nahum 3:4, sorcery)

a) To further help prove our hypotheses, "Philisti" is "Baalis", Palasu (i.e. Palasti or Palestine) from the outdated (Palaia or "Phalasu”), i.e. idolatry and magic. See Joel 3:4-5, Hebrew "Paleste” (i.e. Philistia) New KJV, 2011, Hebrew Old Testament, 2005. Further in Zephaniah 2:5 and Obadiah 1:19 Palestine is Philisti from Hebrew Phalasu or Phalisupha (Ezekiel 8:17 "supha” or losupha, i.e. to commit evil or idolatry). Note Please see the following transliteration rules for transliterating Chaldean "Baalzebub" to Hebrew "Phalisipha" (i.e. the occult).

\section{Statement of Facts of This Study}

\section{This is the Truth}

a) Hence Apostle Paul applied the word "Philosophia" (in Colossians 2:8-23) from the Jewish (Phila) custom (Shophatim; inspired customs, or inspired law, i.e. sepher” Daniel 9:2) but Apostle Paul's argument was that the Jewish law and religion became outdated with the coming of Christ. See Hebrews 7:11 =28, that if the Old Testament is perfect, then Jesus didn't have to come.

b) Hence, Philosophia which is a $100 \%$ Hebrew word means spiritual leaders teaching outdated Jewish customs and traditions (See Micah 1:10-11, Jeremiah 6:26) Hebrew "Philastiaphar" (worthless) or Saphir (i.e. beautiful but false). See Jeremiah 46:19-20, Egypt is "Yaphili saphir", i.e. beautiful but false (Nophili, Isaiah 19:13) Hebrew Old Testament, 2005.

\section{Importance or Relevance of This Study}

\section{(see Translation Psychology in the Research Observations)}

That the original Hebrew and Greek languages or texts of our Bible have in them the true origins and true meanings of philosophy etc., since a deep study of the Hebrew-Aramaic Old Testament and the Greek-Aramaic New Testament presents us with the above words in their original forms; however, once translated to English, they are lost, see (Russel and Choi, (2006) i.e. "Introductions". Please note the following.

a) Levites from Hebrew Lawiyim or Leuyim (i.e. custodians of the law) Deuteronomy 11:18) Nehemiah 8:1-9, Deuteronomy 33:8-10 wrongly transliterated "Levi" and falsified as "priests", rather than priests who interpret the law (Nehemiah 8:1-9, Deuteronomy 17:8-11).

b) Hebrew "Hekonomi" Luke 12:42 (steward: Economist) i.e. Temple or Temple treasury manager (1 Samuel 1:9, Eli the Hecon, i.e. priest).

c) Hebrew “Teqon”, Jeremiah 6:1, Tekoa, i.e. (technology (build or set up) to Greek “Texne” (Arts, skills and crafts).

\section{Problems and Limitations of This Study}

a) Need for more classist (Hebrew, Greek, Latin and other Semitic texts) to be made available for these sort of classist research. 
b) The big problem here, is that our society (e.g. Nigeria and Africa) cannot properly understand English, let alone the Hebrew, Semitic and Greek roots of our modern civilization being falsified and hidden (Philisophoner) in English and French translations of those original classist texts.

\section{Literature Review}

The review of relevant literature focuses on literary and working definitions of the study's terminologies as contained in the study's title and bywords, these which include history, geography, ancient mountain cults, philasaphim.

\section{Definition of Terms (i.e. Etymologies or origins of the Following Study Terms)}

\section{Origins of the Historeo or History}

(Hebrew "Hisara" i.e. Traveler; To Visit and See: Judges 19:17)

- Brown Driver Briggs, 2007, Phoenician Semitic: Sources of the word "History"

a) Hebrew "Isara, Istra, Astra, Astera, i.e. that which rises (Isara) from the East (Estara or Aster; i.e. stars or planets) or the sun (herem: Heraclite) rises from the East; East means the past or the beginning (Eastara, Heastra, Ashtaroth; i.e. ancient gods of the past).

b) Hebrew Old Testament (2005, pp. 1570-1571) Esther is Hebrew “Asthara” (Persian “stara” or “Astara (p 64) i.e. star) to Histara i.e. rising of the sun, or the beginning or East 9i.e. the ancient past).

- Hebrew Old Testament, 2005: Chaldea "Kosodim", "Casdim", Kasdimah or Kedemah, also means "the East”, or the beginning (Isaiah 2:6, 1 Chronicles 1:29 and 31, Genesis 25:3-15, Isaiah 21:16, Jeremiah 2:10, Isaiah 60:7. See Jeremiah 49:28 "Attack ..... and destroy Kedar, of the East.

- Brown Driver Briggs, 2007 (pp. 78-81): “Ishyah” (to support) or Assyrian “Asuria” (Persian “Athura”, i.e. the supporting or gracious god) or Assyrian "Asara, Hasaru" (i.e. go in a straight line, continuous, advance to reach understanding; or the Assyrian and Canaanite goddess of fortune (Felix) "Ascratum" (Ashtarot) or Hashtaro, symbolized by sacred trees or poles. 2 Kings 23:4-10 (Tophel, i.e. idolatry).

a) Hebrew "Ish-arah" (Hisarah: Travelling; or a man who travels: Zondervan, 1990; Brown-Driver-Briggs, 2007: p. 73, Judges 19:17-19, "Hashara" (to travel or wander about) p. 72.

b) P64; ibid, 2007: Persian "stara”, or Aramaic-Parsi "Istara or Esther" (i.e. the Astara, star, Histara, i.e. the beginning or of the rising sun; i.e. the Eastara, Heastara or East, the beginning or of the ancient past; Jeremiah 49:28 "kedar is East".

- Bromiley and Buchsel (1985, pp 377-378: Greek New Testament “Istoreo” or "Historeo” (Galatians 1:18), i.e. to visit in order to know (Historesai, i.e. historicity to visit).

- Robinson and Davidson (Chambers, 1996, p 637): clearly shows that the modern word "History" is from the Greek New Testament "Istoreo" (Historeo) i.e. to visit to know not just to know (Chambers 1996, p 637) but you must go there. Galatians 1:18. Also not from the ancient Greek "Episkope" but a combination of the Assyrian Hebrew "Hisara" and the Aramaic-Canaanite "Istara" (the rising star) to give us "Istara or Histara" (to travel to the beginning).

- Ancient: Metzger (2001) the Greek “Archaios” (Aegea “Achaia”, primeval or primitive people) i.e. early men.

\section{Geography}

- Hebrew Old Testament, 2005: Hebrew “Goiim or Goyin” (Nations or lands, i.e. Ares, i.e. earthly) or people who occupy the land mass (Adamah; ground) called Earth (Aresh or land) Isaiah 14:12 etc.

- Mansoor, 2004 (pp. 235-247): “Gen” or “Geyen”, i.e. garden or land areas for habitation.

- Brown and Comfort, 1990 (Interlinear Greek-English New Testament): “Geos or Ges” or "Gegen (i.e. land, ground soil or earth). The man was created to occupy, till and sow the "Eresh” (Earth) or Gegen (Garden or land; Genesis 3:1-3) Hebrew "Gen" = garden or land. Greek "Geos" = land or earth, soil: Hebrew "Eresh".

- Bromiley and Sasser (1985, pp. 116-117): Greek "Ge” or "Epigeios" “Ge” is land; Mathew 9:26 "Ges" Mark 15:33, Acts 7:3 and 4; which gave us "geography”, i.e. to write (graphe; scriptural or biblical writings or records) of the land (Gen or Geos) or region or district; NRSV, 1990, p. 31). 
- Metzger, 2001: corroborates Bromiley and Sasse (1985) that Greek “Ges” Gen or Geos” (from the Hebrew “Gen”) means the Earth (Hebrew “Eresh”) as a land mass for man to occupy (Shecen or Shecab).

- Aland and Newman 1983: also records the Greek “Ges” as land or earth. See also Barclay Newman (1971) and Nestle (1951).

- Brown Driver Briggs (BDB 2007): clearly shows that the Greek "Ges" (land or earth) is from the Hebrew “Gen” i.e. earth or land, while “Goim” or “Goyin”, means nations. The Ares or Eresh is also earth or land.

- BDB, 2007 and Mansoor (2004): Hebrew "Adamah” means reddish or mud earth (ground) hence man is called "Adam” i.e. created from the red earth or dust called "Adamah".

- Note: Hebrew "Ish” is also man "Esah” (Estrogen, is women) then "Ishyaad” or "Wisdaa” is man's knowledge.

\section{Mountain Cults or the Oikon}

- Wilson 1965, or mountain originally had to do with ridge-like lengths or elevations. Hebrew "Hur”, Har i.e. heights or siphon (i.e. northern) or high lands (BDB, 2007).

- Aland and Newman, 1983: pp. 120-124: Greek “Oikoutos” (sacred house) from the Hebrew "Hekal or Hekon, or "Hekou” (i.e. Temple or God's Palace).

- Hebrew Old Testament: 1 Samuel 1:9 "Eli the Hekon” or (Temple Priest). Priest is Kohen, Khnono or Kono”, “Hekonomi” (Economi, i.e. Temple keeper, or Temple manager, or keepers of the sacred things, mysteries and treasures of God; i.e. the "KORBANAN", or Banka; Temple Treasury (Mathew 27:6), Daniel 1:2, 2 Kings 16:1-7-10, 2 Chronicles 31:1-15.

- Mansoor, 2004, vol. 2: Hebrew “Hekal” vol p 247, Hebrew “Hekal or Hekou” (Greek “Oikou” or “Oikoutos”, i.e. the occult, or secret sacred assemblies).

- Hence, Hebrew Old Testament, 2005: KJV Ecclesiastes 12:11 “Baalisophot” (is Baalzebub) transliterated to the Hellenist-Hebrew "Philosophia” i.e. leaders or masters of mountain (phila or ophel; Nehemiah 11:21) cults (i.e. Oikou from Hekou) i.e. secret religious places for consulting occult or secret powers. (See our transliteration rules on the next page).

\section{Hebrew "Philashaphim", Gave Us Philosophia}

(i.e. Spiritual Leaders and Kings (Phila) of Mountain Cults (Sophim) Ecclesiastes 12:11, Numbers 23:14)

- Brown-Driver-Briggs, 2007: pp 62-65: Phoenician "sophot” (secret assemblies) Aramaic-Hellenist, Hebrew cognate, "kahal or koholet, or Ekkle (i.e. religious assembly) which gave us "Ekal”, Ekol, Ekklesia, Ekonome (i.e. Religious gathering) Gathering is Phoenician “Asab” (Assembly or Asaph, i.e. Sophot, to Philosophon, i.e. spiritual leader) see Goodnews, 2008; Ecclesiastes is philosopher. Robinson \& Davidson (Chambers 1996) cult is secret and spiritual. while the occult is Coptic-Phoenician "Belatehen”, or Hebrew "Philoot” i.e. mysterious, extraordinary; or Philu, i.e. find out by casting lots (1 Samuel 14:42 "Philu”) Goodrich and Kholenberger (Zondervan, 1990) Hebrew "Sophoner", Phoenician "Sophot” Chaledan-Semitic “Zaphenath”; Egyptian “Zaphenath” (Genesis 41:43-45) Greek "Sophonias” Hellenist-Aramaic-Hebrew "Koholet” to Greek "Oikoutos” (all means secret assemblies or the occult translated as "Masters of Assemblies" should be "masters or leaders of secret or occultic or cultic assemblies, who claim to be teaching wisdom called “Asaphim” in Hebrew (Ecclesiastes 12:11; see Daniel 4:9 and 18)”Aphialsaphir”; i.e. chief magician or chief priest or extraordinary powers) NCB, 2008. Pilaot (Plato) or Hebrew Philaoti to Philosopha (Job 5:9; unsearchable) (philosophia-the mysterious; Orphicsopherim; mysterious teachings) Woodrow, 1969: pp. 70-71 (that human reasoning (soephi) can search out the spiritual (orphi or phili).

- Robin and Davidson (Chambers, 1996, p 1100): Hebrew "Phili” means extraordinary. (Greek “Orphic”).

- Hebrew Old Testament, 2005, Job 5:9: “Niphilaosapher” (i.e. uncountable, unsearchable, inexplicable).

a) Hebrew Old Testament (KJV, 2005, Ezekiel 13:18-20) Hebrew Ephramite "Pilos, Pillows, Pileset, Philos, Philisti” (magic: check NIV) or Phalasu, Tophalasupha Psalm 58:2-3 “corrupted”; 2 Chronicles 15:16 "Miphilasu” (i.e. repulsive sexual idolatry; Goodnews, 2008).

b) See Exodus 7:11 Phoenician “Vilasaphim” (Aramaic “Philasophuim”, magicians). Ali, (1970) Arabic "falsafa” from Hebrew Philasapha” to English "falsify".

c) "Philisophiqu”; Job 34:37 "Losophiku” (i.e. Philistines mock god. They are pagans, idolatrous, and they follow many gods (Phalisaphar; Isaiah 41:24, i.e. man made gods). 
d) Job 34:32, "Phalisipha” (evil)

e) 2 Kings 10:23 "Phensopha" or "Phelisopha” i.e. worshippers of Baal, or following "Phalasu” or "Philisti"; i.e. many gods (2 Kings 1:1-3) etc. Goodrich and Kholenberger (1990) "Baalzeboul and Baalzephon" is Phalasophon Isaiah 50:8 (i.e. accuser or opposer of God) see also Nahum 3:4 "Baalcosophim" (Phalasephim, cesephi or Asaphim, i.e. consulting witchcraft or invoking the dead; 1 Samuel 28:1-7) Brown-DriverBriggs, 2007: p. 80.

- Brown Driver Briggs, 2007: pp. 100-1076 “Tophetsophet” (consulting gods through divination). 2 Kings 17: 29-31.

- Hebrew Old Testament, 2005, Jeremiah 19:5-6, Jeremiah 7:29-30 Tophili Serphim (fire divination to Baal or Phalasophet).

- New and Philips, 1953, Heraclitus of Ephesus in Asia Minor (Ionia) got the word "Sophet" from Ionian Jews that the mystery of existence i.e. is in the divine fire "sophet".

- Note: The Hebrew "Herem" (the sun fire) gave us "Heraclitus" (Greek "Helikos or Helium”, is the sun).

- Boer, 1980: pp. 5-30 corroborates New and Philips, 1953 and that Heraclitus (Heresu; i.e. Hebrew for the sun; BDB, 20070 was taken to the gates of the sun by a divine being).

- Hebrew Old Testament, 2005, Genesis 15:5: "Losapher" (to number or count; Assyrian-Chaldea "Man or Mangi") then see Job 5:9 "Niphilaosapher", i.e. uncountable; cannot be numbered and unsearchable. Obviously, the Greek "Anthanses "Arithmos" (Arithmetic; i.e. numbering; Newman, 1971) clearly shows that Ionian Pythagoras of Asia Minor got the word "Philosopher" from the following Hebrew roots:

a) Hebrew "Philaosopha" (to count or calculate: Job 5:9, Genesis 15:5). Also....

b) "Philisophis" (crafty serpent, or the occult) from Ionian Asia Minor Jews definitely since "Saphar" or "Sopher" is Hebrew for numbering and teaching; (in Greek it is "Arithmos" and "Didactos" or Didaskalos while the Hebrew "Sophis" (serpent or to be crafty) is Greek "Pytho" (Pythagoras; Acts 16:16, spirit of fortune telling).

Note: The Hebrew “Aron” (Aristotle) is also craftiness or cunning.

\section{Analytical Method of Study (Research Design)}

\section{Please Note:}

a) Classist Chaldea (Casdim, Wasdim = wisdom), Hebrew, Greek, Syria, Assyrian, Aramaic, Phoenician and Latinized texts have been consulted since the word "Philosophy", has its roots in ancient languages and texts, 3000 years older than Greek and Latin.

b) Daniel 4:9 and 18 gave us "Philosophia", in its present form. Daniel was called "Aphilasaphir" (chief magician) from an older Sumerian/Chaldean (Babylonian) Baalzeboul or Baalzephon (Exodus 14:1, 2 Kings 1: 1-3) transliterated to Hellenist-Hebrew "Phalasapha”, Arabic "falsafa”, English "falsify", i.e. Baal's mountain (Ophal) cults (sophot) that issues false messages (e.g.) the Mountain (Nehemiah 11:21, Ophal, or hill: Numbers 23:3-14; or Phaal) cults (Sophim) of Baal or Delphi on Mount Parnassus outside Athens.

See Numbers 25:1-3 "Baal-Peor" (mountain cult of Baal) Numbers 23:3 \& 4 "Balaamsophim" (or Zophim) "Phalasophim" (Hill of false prophecy or false watchmen.

c) Very Important: Phoenician (1900BC) literature gives us the word "Pilisti" (Philisti) from "Pileset" or Mipalasu (Palasti or Phalasu; i.e. idolatry or worshipping many gods or many elements; Isaiah 2:3, 2 Samuel 5:21, 2 Kings 1:1-3, "Baalzephon (Exodus 14:1) or Phalasephar; 2 Kings 17:29-31, i.e. he who consults mountain gods or mountain cults of Baal; e.g. cult of Delphi in Greece.

d) Note: Isaiah 2:6 "Philosophiku" (Philistines mock God through foreign gods and senseless paganisms, including soothsaying; see 2 Kings 1:1-3 to consult "Baalzeboul” see Exodus 14:1 "Baalzephon" (Phalasephon) mountain cults of Baal (Very Important; Baal or Phaalisipha; he who attacks or opposes; See Isaiah 3:17: to attack.

1) Obadiah 1:20 "Sepharad" (Israel in exile mourns in lands of captivity idolatry) see the original Hebrew KJV 2 Kings 17:29-31; Sepharv: i.e. divination gods of Sophara.

2) Philosephar: Isaiah 17:21 (Isaiah 2:21 mountain tops of the gods (consulting the gods).

3) Isaiah 17:13 "Phanisupha" (Philosupha) floating aimlessly in the wind without foundations, but cleverly invented (sophis; or crafty serpent; 2 Peter 1:16).

4) Isaiah 2:20 "Elilicasophu" (gods of silver) to "Phalisophu" (he who consults the gods of silver) see 2 Chroni- 
cles 23:1, "Elishaphat" (God judges or speaks: then to "Phalisaphia” (beautiful but false Human judgments and conclusions, Colossians 2:4) BDB 2007, pp 45-46.

Note: Very Important: See Joel 3:5-6 "Casophu" (they carried my silver and gold, zahab = zahaphi) to Greece, then "Philosophu" (he who studies the finest ideas and silver gods of Jerusalem that led to the Jewish exile.

5) Read 2 Kings 16:7-18 "Phileser-Asshur” (Philesaphir) (not Pileser) i.e. the divination king of Assyria (i.e. idolatry: consulting gods and spirits) Hebrew Old Testament, 2005.

\section{Bible Translators Are Philosophers}

\section{(see Translation Psychology)}

Please Note again (i.e. Bible Translators Often Hide or Cover up Truths about Philosophy)

1) Check 2 Kings 16:10; Hebrew "Phile-asur" (or Assyria; see 2 Kings 17:29-39, 2 Kings 18:34, "Sephar”, i.e. gods brought by Assyria) i.e. "Phileasur", is Philesephur, i.e. kings who consult manmade (phesel) gods (sephur, or sephar or sephir from sipiri, i.e. spirit: Daniel 4:9 and 18, Isaiah 30:22, 2 Kings 18:34; see Genesis 10:30, mountain of the gods-i.e. Sephar in Keda (the East: Ezekiel 8:16).

2) The sun god, is Baal or Phaal-sephar (i.e. consulting elemental manmade gods. See Colossians 2:8-23, Isaiah 41:24 etc.

\section{Evaluation of the Study's Methodology}

\section{Very Important}

a) The above points under our method of research is that its classical-Hebrew-Phoenician approach (i.e. consulting ancient Semitic texts) clearly reveals that the word "Philosophy" has a huge geographical transmigration that never started from Greece (but from Chaldea-Assyria and Arabia) but passed through Greece; then staying in Greece longer than expected; long enough to be called "Greek", but truly not Greek.

Also Very Important: check Daniel 3:10, Hebrew "Siphonihon” (all kinds of music; 1 Kings 18:21—“Phalisophim”, following many opinions)

b) Particularly after checking through over 80 honest Greek lexicons, the word "Philosophia" never appeared anywhere as a single word, but a merger of "Philos" (Hebrew "Phalhi" prostituting or sexual immorality) and Aramaic "sophra" (teacher of magic). Please Note: this Philosophy was transliterated from the "Baalisophot" see Exodus 14:1 "Baalzephon", or 2 Kings 1:1-3 "Baalzeboul” (Zeboul is saphon: i.e. North or Mount: Hebrew "Ophel”, sacred hill; Nehemiah 11:21) cited in Ecclesiastes 12:11, "Baalisophot" (from Ezekiel 13:18-20) "Pilosophaot" to Colosians 2:8 "Philosophia”, i.e. leaders of the occultic or false teachings from the sophaot (i.e. veiled or secret assemblies: philasophot) see Exodus 7:11 secret arts (Philatehem) of magic (Ashaphim, Assur) from the East, i.e. Chaldea, Assyria and Babylon (Kedema, or Casdim = wisdom or wasdim; Daniel 2:2,10, Daniel 3:8).

c) They gave Egypt “Vilashaphim” (Philasaphim, Exodus 7:11, i.e. magic erroneously called wisdom; see 1 Timothy 6:20.

d) Check Daniel 2:4, Daniel 4:9 and 18 (Daniel 2:4 "Uptasaph" and to interpret through magic, i.e. pilos, Ezekiel 13:18, KJV, Daniel 4:9, “Aphialasaphir”, chief magician, Daniel 1:20, Daniel 2:2-27.

e) Hence, all the classical or ancient Greek philosophers who went to Egypt to learn philosophy actually went there to learn "Philasaphim" (i.e. finding out things through the Hebrew "Philu", i.e. magic or sercret arts. 1 Samuel 14:42, Jonah 1:5-9, Nehemiah 11:1) at the Egyptian "Nophili" (translated "Memphis" to cover up or deceive) see KJV Isaiah 19:13, Jeremiah 46:19, and from the Egyptian oracular gods "Zaphenath" (Hellenist-Hebrew "Sophonias" or "Zephaniah", i.e. hidden or secret or inexplicable; see Daniel 4:9, "Sephur or Sipiri; i.e. spirits or gods).

f) Note: Isaiah 19:13, and Jeremiah 46:19 in KJV used the original Hebrew word "Noph" for Egypt which means deceit see Acts 7:19 "Pharaoh Sophian" (i.e. deceived the Jews) while NIV Isaiah 19:13 used "Memphis" (i.e. deceived) (see its footnoting, "13C” reads Hebrew "Noph”). In like manner, Obadiah 1:20, KJV is "Sepharad"-(Jews exiled to mourning in pagan Ionian lands, i.e. Asia Minor) 2 Kings 17:29-30 "sephar" (gods) in NIV and NCB, it is also "Sepharad", but in Goodnews (the Catholic translation) it is "Sardis", the modern name: A Question: why avoid "Sepharad"? Answer: because it is an ancient root of Philosophia, as 
Greek paganism (sophiku: Isaiah 2:6); i.e. consulting many gods or following many ways see 1 Kings 18:21 Hebrew "Baalsoephim" (Divided opinions; or followings many ways or many gods).

g) Hence, Philosophia means he who teaches and follows many ways or opinions. Not founded on or resting on one solid opinion. (See Job 37:16, Hebrew "Miphiloseph" (floating or trying to balance) Hebrew Old Testament (2005).

h) Isaiah 41:18, Hebrew "Eph-the-al-Shophiyim” (from Baalsophim) i.e. secrets are opened up in mountain cults.

i) Properly transliterated in Daniel 4:9 and 18 "Baalsoaphim or Baalzeboul” is "Aphialsaphir", i.e. he who speaks from the gods (or chief priest, or chief magician), i.e. Beltesazzar. (Aphilasaphir gave us the present spelling of philosophia: see 2 Kings 17:29-34, "Phi-lashaphat" (pagan (pili) palasu or Phalasu or Philisti, i.e. magic or repulsive pagan customs and traditions. Compare this to Colossians 2:8-23 and 2 Chronicles 15:16, Isaiah 2:6.

j) Zephaniah 3:8 Hebrew "Losopheq" (to pour anger or accurse) "Philosophet”, i.e. he who accuses or opposes). Also, Zephaniah 3:8 Hebrew "Lasophu” (to gather; Asaph; 1 Chronicles 16:5 i.e. Asaph first (Phal) i.e. Abiasaph or Phalasaph; he who gathers or leads the assembly or a religious cult; i.e. spiritual leader.

\section{Classist Geographical Data History}

a) A good look at our textual methodology above explains this presentation of geographical data in the occultic origins of philosophy from the Kedema, Casdim or Casaphim (Cosodim or Cashdom-to wisdom: Isaiah 2:6 "Philisophiku" (i.e. mocking God with idolatry or pagan gods) or consulting the one who (Phe = speaks) to the gods (sephir; sipiri; spirits)Daniel 4:9, 2 Kings 17:29-30; Note: the oracle (Hebrew Sophat) of Delphi or Egyptian Nophili; i.e. (deceit), Isaiah 19:13, Jeremiah 46:19 (use KJV).

b) Note:

1) Romans 1:30 (22-32) the ancient world thought they were wise (Daniel 8:5 and 21 called Greece "Sephir = Zepher, i.e. goat) but they were fools worshipping reptiles (epeton) or serpents (ophis-sophiphon) and developed cults (sophaot) Ezekiel 13:18-20; veiled or secret cults (sophot) called the Ophites (McCain, 2005) who worshipped the serpent (sophis or Nahasuphia) as symbol of Casdom or Casopham, i.e. wisdom) 2 Kings 18:4 "Nehustan" or Nahasophion (serpent worship; Numbers 21:6-9).

2) Note: Romans 1:30 clever inventors of fables or Greek "Epheure", Hebrew "Yaphial", i.e. beautiful but false (Colossians 2:4) then see 2 Peter 1:16, Greek "Sophis” from Hebrew "Sophiphon” (i.e. serpentine) or cleverly invented or crafty.

c) Very Important: See Mathew 10:16, Jesus said "be ye as crafty as serpents (ophis-sophis: Revelations 12:9 (7-10), Genesis 6:4; Nephilim (the giant angel rebels were cast down) with their master "Satan" called the accuser, Isaiah 50:8, Phoenician "Baalcosophim", Hebrew "Phalasophim”, Arabic "falsafa” (English "falsify") to New Testament Greek "Ophilosophian”, deceiver, seducer, liar (Colossians 2:8, Hosea 7:1 "Phalasaqer”, falsehood or phalasaphaq, i.e. the lair or he who mocks God. See Isaiah 2:6 "Philisophiqu”, i.e. philistine mock God with Satanism, magic, paganism, idolatry or foreign gods.

\section{Transliteration Rules}

Ancient Phoenician "B" is Hebrew and Greek "Ph" or "P" while "Z" is "S", hence Baalzeboul or Baalzephon i.e. Phalasephou (i.e. consulting the occult) see Revelations 9:11, "Abad is Phal or Apol( to destroy) Balm is Rapha or Pharm (healing) Abba is Patria (Baba is Papa) see Genesis 35:19 "Bethlehem" is Ephrath etc, while Zion is Sion: Zadoc is Sadducees, Zidabiq is Sidiq etc. (See Genesis 21:22 "Baal” or "Phicol" (is lord or leader) BDB, 2007, pp 126-129, "Eluphi” (chief or lord), which gave us Hebrew "Alephili” (Lordship, first or to lead); to Greek "Alpha” (Lord: Alpha and Omega, Revelations 1:8 "I am the Alpha and Omega (first and last) says the Lord”. NVB, 2008, p 2230: see the Hebrew Old Testament, 2005, “Aluph” (Chief).

\section{The Implication of the Above Transliteration Rules}

Applying the above transliteration rules to Colossians 2:8 "Philosophia", Phila is Jewish spiritual leader; God separates (Phila) Jews from Gentiles (Goyim, Ger or Grea; i.e. other nations or gentiles) to constantly teach true 
religion (sopherim) to other nations: see Ezra 7:11-12, Nehemiah 8:1-9, “Sopher” (scribe, means learned priests, not just learned) this which is Leque, Proverbs 5:11-12.

\section{On the Map (Figure 1)}

\section{Note: (Ancient Mountain Cults Called “Assemblies” Phala (Sophot) in Ecclesiastes 12:11.}

a) Study the above map carefully, then go to Acts of the Apostles, and compare this map to Apostle Paul's missionary journeys. The above map clearly shows when and where Apostle Paul carried his mission works to the question is,"why to Asia Minor and Ionia": very simple.

b) Jews built Asia Minor before the exile of 586BC (by Nebuchadnezzar) which took more escaping Jews to that place; Joel 3:5-6.

\section{Data Analysis}

The ancient maps (i.e. Geography of occultic origins) of philosophy.

Figure 1: Chaldea, Sumeria and Accad (5400 BC) Goodnews-Collins (2008).

a) Please see Genesis 15:7, Hebrew Old Testament (2005, pp. 20-21), that Abram was brought out by God from Ur of the Chaldeans (Mesopotamia; i.e. Assyria and Babylon) the Philesos or divination kings). This is how it was written in Hebrew Old Testament, "Ur-Casodim”, (i.e. Land of Astrology or those who count or study the stars i.e. Hebrew "Losopher" (Job 5:9 and Genesis 15:5, Niphilaosopher; i.e. uncountable or unsearchable).

b) Genesis 15:7 “Ur-Casodim” (1950BC) Daniel 2:2, Daniel 3:8 etc astrologers gave us “Usodim”, or wisdom, i.e. Chaldea (or Kasdim or Kedemah) easterners who gave us ancient wisdom of reading the stars (Hebrew "Asaphim”, or in Persia it is "magos”: Mathew 2:1-12, i.e. Persian chief priests.

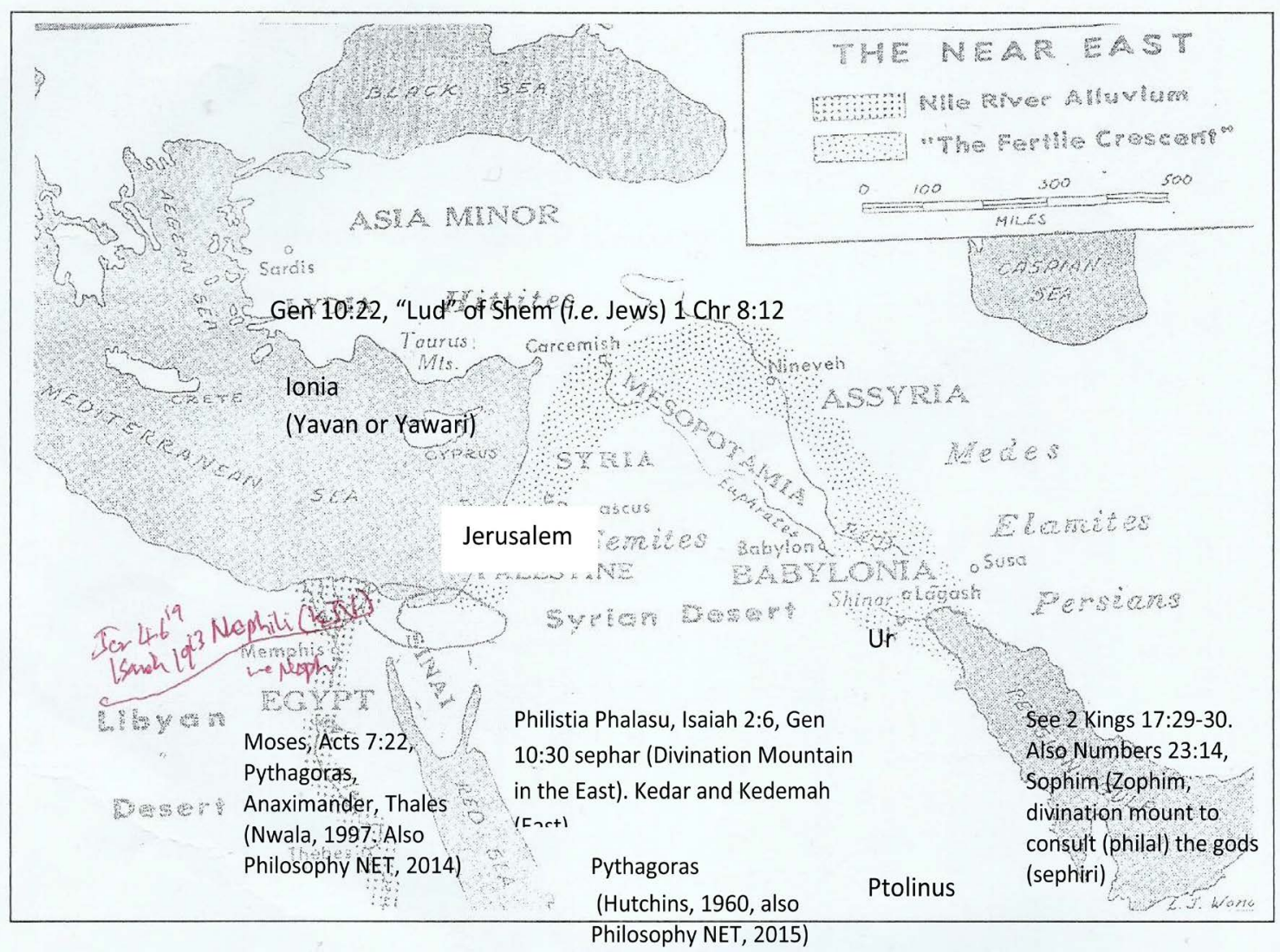

Figure 1. Ancient Divination hills and mounts (Tophilisophim: Jeremiah 19:5-6, Numbers 22:41, Numbers 23:1-end). 
c) In Daniel 4:9 and 18, chief priest is "Aphialasapir" (i.e. chief magician or extraordinary powers, or the divine power of the "Phetah" (i.e. interpretation of mysteries; Orpheos: Woodrow, 1969: pp. 70-71). Genesis 14:1 "Amraphel" (king of Shinar or Babylon; (1920BC) or 2 Kings 16:7. Tiglath-Phileso or Philasaph (Pileser; i.e. divination or occultic king of Assyria, 2 Kings 16:7-18).

On the Map above: Note:

1) Jews built Ionia and Asia Minor Genesis 10:22 "Shem produced Eber and Lud (Lydia; i.e. Asia Minor and Ionia).

2) Ancient Greek philosophers entered Egypt through Jerusalem (Boer, 1980: pp. 8-20).

3) Jews called Greeks "Phalasu” (Gentiles) or "Phalisipha” (i.e. pagans, Isaiah 2:6 "Philesu” or Phalasaphar; Isaiah 2:6 "Phileso" or Phalasaphar; Isaiah 41:24, “consulting man made gods” (Hebrew “Aphialsaphir”, Daniel 4:9 \& 18—carved images of magic, or saphilsaphim; Isaiah 8:19 (Necromancy).

On the Map (Figure 2)

Note: A-E, Very Important:

a) Study the above map carefully, then go to Acts of the Apostles and compare this map to Apostle Paul's missionary journeys. The above map clearly shows where Apostle Paul carried his mission works to: why Asia Minor and Ionia? Simple.

b) Jews built Asia Minor before the exile of 58BC (by Nebuchadnezzar) which took more of escaping to that place. Read Joel 3:5-6 "You carried Jerusalem and Judah, and my "Casophi" (i.e. finest silver, gold and arts) to Greece called "Yavan" in Hebrew; i.e. Ionia, where Hellenism and Judaism met.

c) From this same Asia Minor, (also called Ionia) Pythagoras, Heraclitus, Thales, Anaximander, Anaximenes, Empedocles etc (during that Hebrew exile era 600-450BC) all of them had Jewish and Greek backgrounds or parentages (i.e. if they ever existed).

d) They travelled from Asia Minor to Egypt by land, you cannot enter Egypt by land without passing through Jerusalem.

e) They got the word Phalisipha (pagan teachings) from Jews and took it to Athens.

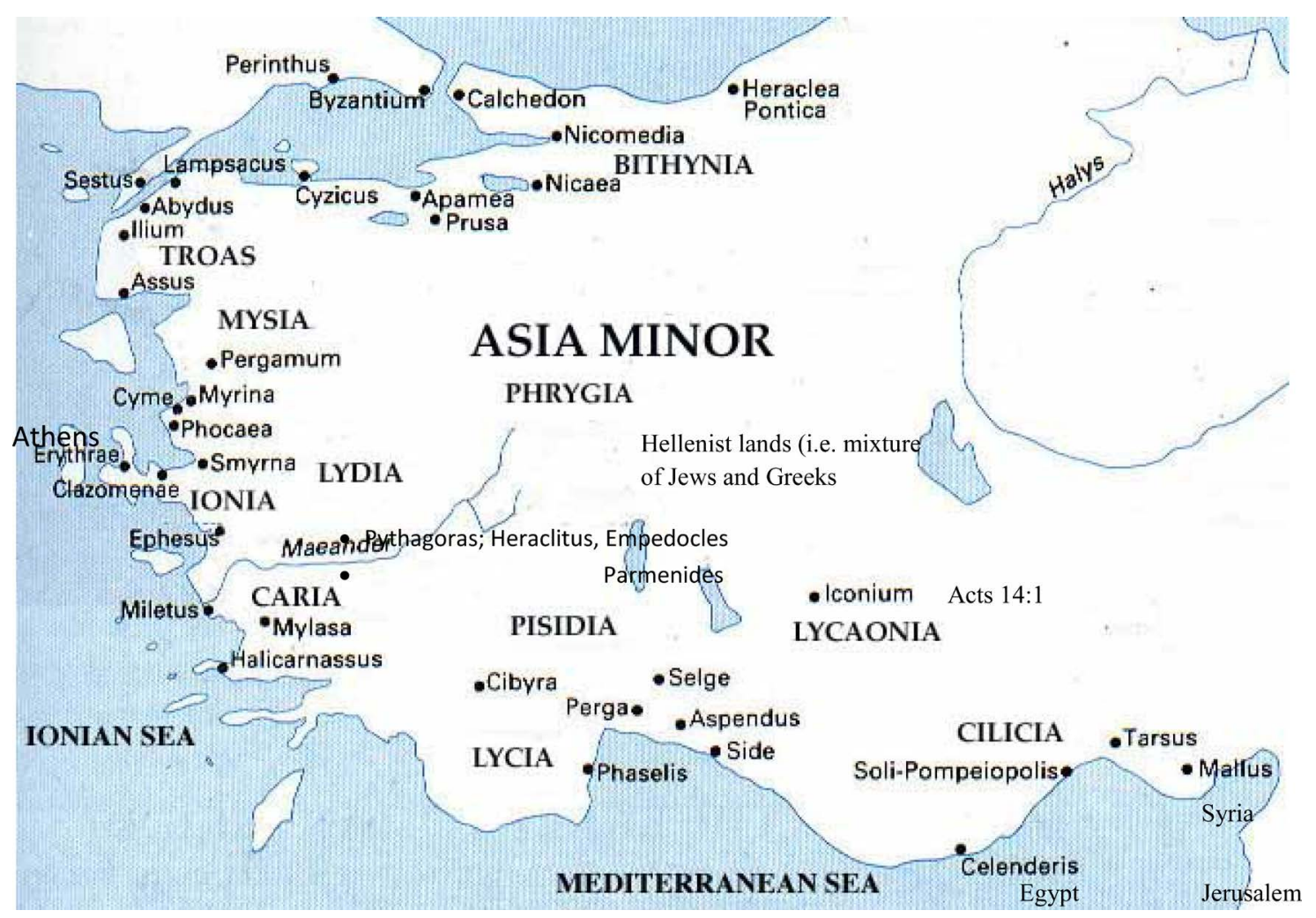

Figure 2. Inter-Testament (Jewish Exile lands) Asia Minor (or Ionia) see also Jewish Ionia, New and Philips (1953) and Maier (1988). 


\section{Earliest uses of the word "Philosophy” 2100BC Aramaic (i.e. Syriac)} Note:

i. Please see Psalm 58:2 “Tophalesun” (Aramaic "Phalisupha” see Job 34:32, "Phalisipha” (i.e. corrupted, tainted or evil).

ii. Exodus 14:1 is Ephramite "Baal" (Paliaa) zephon (saphem) i.e. mountain cults of Baal, which is Genesis 10:30 "Mount (Harar or Sephara) or Sephar; i.e. Balaam or Phelasophim (consulting gods at the mountains in the East, i.e. Kedemah).

\section{Research Conclusions, Research Findings and Recommendations}

\subsection{Research Recommendations}

That dictionaries of current English e.g. Hawkins (Oxford; 1995) Robinson and Davidson (Chambers, 1996) Simpson and Weiner (1989) etc. do not necessarily contain the true origins and true meanings of current English words; why? Simple. Anti-Semitism, this should be the focus for future studies. (See McCain, 2005, also Russell et al. (2006).

\subsection{Major Research Observation}

Translation Psychology is the behavioural human tendencies to cover up ancient truths while translating ancient texts e.g. KJV, Isaiah 19:13, Jeremiah 46:19, Egypt in the original Hebrew is called "Nophili" (i.e. to deceive or worthless). In translation, "Memphis" is used rather than "Nophili", to cover up the true origins and meaning of philosophy etc. 2 Kings 9:30-37 "Phoenician" "Zebel” (i.e. corrupt) or Yezebel, i.e. Jezebel, is Hebrew "Tephel” (wickedness: Psalm 58: 2-3 or Tophelsaphan)

\subsection{Major Research Findings}

a) That KJV Ecclesiastes 12:11 Phoenician "Baalisophot" (Aramaic "Phalisophot”, i.e. leaders of mountain cults gave us the word "philosophy", Hebrew Old Testament, 2005.

b) That the words "Sion and Sinai" (Exodus 19) are originally of Phoenician "Ophi” or Soph (Numbers 23:3) and v 24 "Sophim" (or Zophim) i.e. prophetic watch tower mounts for consulting the gods.

c) The words "Philosophia and Philosopher" are of different origins.

1) Philosophia means consulting gods of the mountains (Numbers 23:14).

2) While philosopher means outdated wonder or mysteries, i.e. (philo) teachers (sopherim) or teachings.

\subsection{Major Research Discoveries}

1) That the first ancient use of the word philosophy was in pre-history. Genesis 11:7 and 9, Phoenician "Balusaphat" (Hebrew-Aramaic "Phalisapha") i.e. divided, confused language or teachings (Peleg or Pheleg or Phalasaphar (Genesis 10:25) or Blagsapha (i.e. Blasphemy) Psalm 55:9, "Phalaglosona” (Genesis 11:7 and 9), i.e. confuse them.

2) Particularly, Genesis 41:45, Egyptian "Phanesophena” (Hebrew "Phelosiphri”, means man made gods speak through the masters; i.e. phal).

3) Also, KJV Isaiah 19:13, Jeremiah 46:19, "Egypt" is "Nophili”. Her magicians are the "Lasaphim” (astrologers). Hence, what ancient Greek students learnt in Egypt was "Nophilasaphim”, i.e. Egyptian magic, falsely called "wisdom" (1 Timothy 6:20: Greek "Gnoseos to Gnosoph", i.e. science, secret or mysterious knowledge, Exodus 7:11 and 12, Daniel 3:8, Daniel 2:2-27.

4) The word "wisdom" is not from German-Greek, "Visdeion or Wissen" (Metzger, 2001: pp. 60-79) but from the Chaldean "Casdim" (astrology and the Hebrew "Yadaa, Wadaa or Yisdaa, i.e. to know, Genesis 19:5-8) Daniel 2:2, Daniel 3:8, Mathew 2:1-2 etc.

5) Byzantine wisdom was "Hagia Sophia” (Holy Wisdom) in opposition to Catholicism, "philosophia (i.e. pagan wisdom).

Note: Casdim and Yisdaa gave us "Wasdim or wisdom”, i.e. to know through the stars (stara) or astrology, Hebrew Old Testament, 2005; Brown-Driver-Briggs (BDB, 2007) pp 64, 506, 355, 402 etc.

The conclusions of this study are projected from the research findings which have been clearly stated below. 
6) See also Job 36:18, the Canaanite-Hebrew "Baalsaphaq" to Phoenician-Hebrew "Phalasaphaq" (i.e. to lead away or astray), Psalm 40:14-15.

\section{Additions: Philosophia Origins}

Please Note (Figure 3): see Revelations 9:11 for transliteration rules e.g. Abad is Apol; Zion is Sion, Baba is Papa: Izhak is Saak etc.

1) Basic conclusions of this study are projected from its findings is that the Greek Philosophia was a $100 \%$ transliteration from Phoenician "Baalsophot", or the Hebrew "Aphilasaphir" (Daniel 4:9 and 18) and 2 Kings 10:23 "Phensapha" i.e. Baali chief magicians or chief priests (i.e. extraordinary occultic or secret powers; Exodus 7:11-22) Hebrew Old Testament, 2005.

2) That the above Hebrew "Aphilasaphir" (Exodus 7:11 Coptic "Vilashaphim”, magic or occult powers was a transliteration from the Phoenician and Eastern Chaldea (Babylonian) "Baalzeboul", "Baalsephon or Belteshazzar", i.e. serpent cults of inquiry; Hebrew "ophen-sophis", Mathew 10:16—crafty serpent; Aland and Newman, p 103.

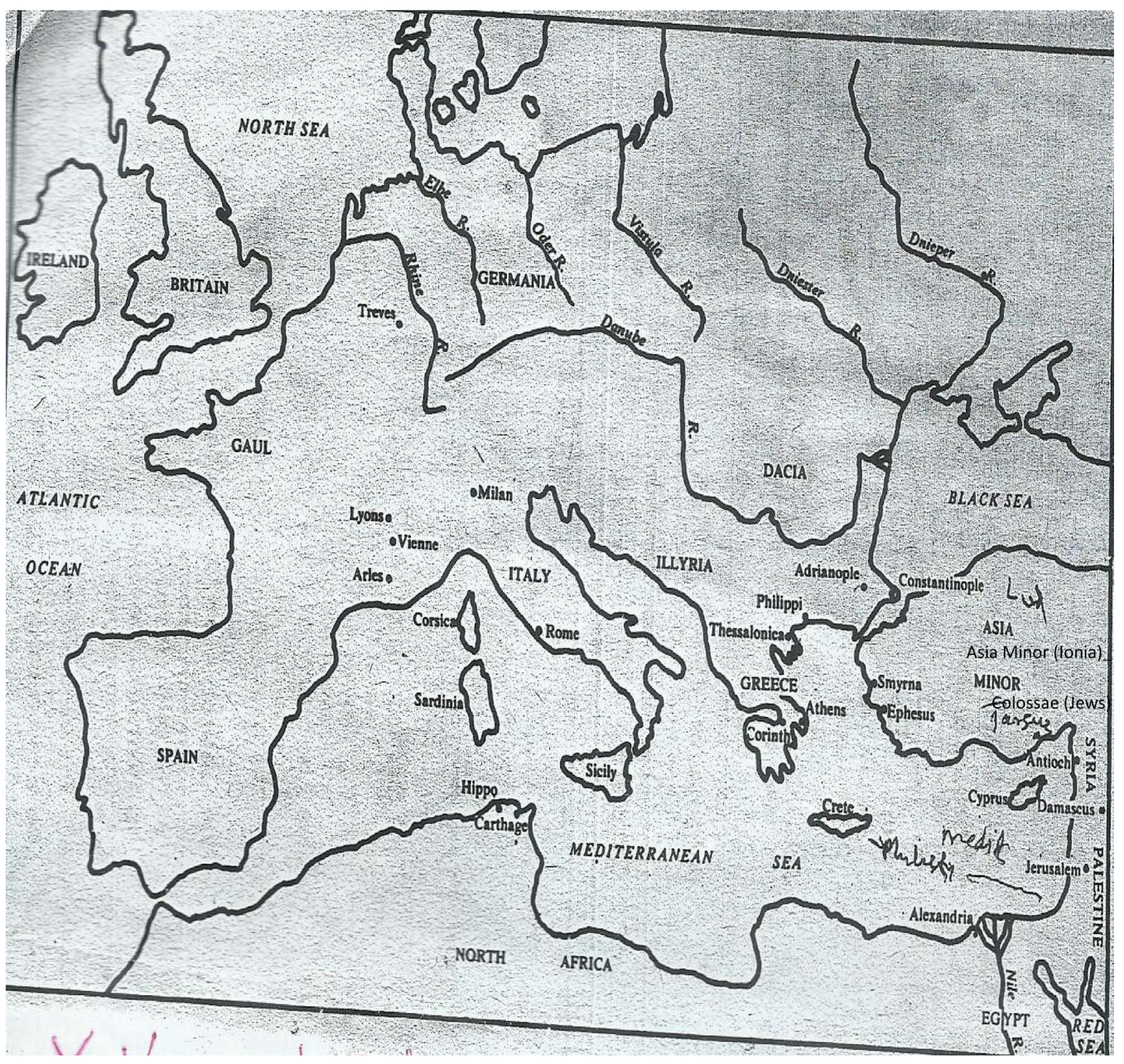

Figure 3. Colossians 2:8 Asia Minor (or Ionia) showing Galatia and Colossae (i.e. New Testament Asia-Minor Boer, 1980) c50CE. 
3) A good look or study of our data maps clearly show that the word "Phalasophim" or "Philasapha" (Arabic "falsafa", English "falsify") were used by ancient Jews to refer to nations of idolatry (i.e. Baali to Phaali: Chaldea: Ezekiel 23:1-end) and pagans (Philista) as "Phalasu" (or Phili to Philisti) Isaiah 2:6 (KJV: Pillows, pila or philo, i.e. magic) or Baal to Phaal to Phaulo (Revelations 9:11) i.e. false; James 3:13-17, Hosea 7:1, i.e. "Phalasaqar" (falsehood) or phalasaphaq—see Isaiah 2:6 "Philisophiku", i.e. the liar, or he who mocks God with pagan or foreign gods. Woodrow, 1969: pp. 1-4.

4) Hellenism was clearly called "Phalasu", i.e. Philisti or paganism, i.e. godless people or worshippers of false gods or followers of divided and divisive opinions called "Baalsoephim", (Exodus 14:1 "Baalzapha" i.e. Mountain cults of Baal, i.e. falsehood).

5) That from the Kedemah (East) or Casdimah or Chaldeans (in ancient Mesopotamia of Assyria and Babylonia) came the "Baali", "Phaali" or "Phileso" (i.e. Pileser; 2 Kings 16:1-7, 7-18, 718 BC) NCB, 2005) that "Philasophim" was an over 8,000 years old "Casodima" i.e. wisdom" or ancient idolatry (1,500 years before Athens) for consulting the dead "Saphilsaphim" (Isaiah 8:19) and 1 Samuel 28:1-11 "Baalas-ob", 2 Kings 1:1-2 "Baalzebub” or Exodus 14:1 "Baalzephen” or Mathew 2:1-16 Persian "magi”, Hebrew "Ashaphim” or Aramaic "Ophen-sophen" (Mathew 10:16, be ye as crafty as serpents; i.e. ophites who worshipped the serpent as source of wisdom, judgment or healing. Numbers 21:6-14, Acts 28:1-9 etc) or further still Balaamsophim (Numbers 23:14) i.e. mountain of false prophecy, transliterated to Hellenist-Hebrew as "Philosophia" (i.e. Colossians 2:8, as falsehood, and empty deceit).

6) Genesis 10:22 that "Shem" the father of the "Semites" (including Eber, i.e. Abraham the Hebrew: Genesis 14:13 was also the father of Lud who built Ionia and Asia Minor: i.e. Ionians and Asia Minor (Sepharad or Lud, Obadiah 1:10) was originally Hebrew before the Greek invasion.

7) That the word "Amraphet (or Ahitophel) i.e. Genesis 14:1 (1,900BC) is the same as "Phileso" (2 Kings 16:7, i.e. Pileser (718BC) which is from "Baali", "Abaali” (Revelationss 9:11) or "Balaamsophen” Numbers 23:14, or Numbers 24:1 "Apham or Bapham" i.e. Pharmakon, magic or magic healing) which means divination leaders and kings, or he who teaches how to find out things through magic (philos or pilos) at the occult (Sopaot, sophaot, or veiled, or secret cults: Ezekiel 13:18-20) which Apostle Paul totally condemned in Colossians 2:4-8 (8-23) i.e. the teachings sound beautiful and true, but they are totally false, idolatrous, or customs and traditions mixed up in true doctrine (see Woodrow, 1969) pp 1-150; i.e. Babylon or Phaali, the falsehood that entered Catholicism.

8) That a linguistic study of the words "Prophet" (Pro-ophet: i.e. receiving messages through extraordinary means before it happens is the same as "Philos-ophet", i.e. false (Phaulos) claims to receiving divine messages. This can be gleaned or seen from Isaiah 56:10, i.e. Hebrew "Evilsophe" or "Philiasophe", i.e. blind or false prophets (see Mathew 15:14, 2 Corinthians 14:4, i.e. Greek "Tuphlosen”, from Hebrew "Tophilaso; Ezekiel 22:28, Jeremiah 19:5-6 = Tophet; or Ephelasophe, i.e. those prophets who falsify their messages or claim God spoke to them: Jeremiah 14:14, Jeremiah 23:21-25 etc.

9) That the oracle of Delphi (originally called "sophis or pytho, i.e. serpent) outside Athens, towards the North, on Mount Parnassus (New and Philips; 1983: pp 94-96) was a 100\% replica or an ancient design to correspond to the Chaldean "Baalzephon" (Baalsephon: Hebrew "Phalasophen) or the "Baalzeboul” (Hebrew "Phalasaphou", i.e. serpent or crafty spirit of inquiry; Aland and Newman, 1983: p. 157).

10)That the ancient Greek goddess of wisdom was called "Pallas-Athene" (Hebrew "Phalasophya", i.e. crafty serpent goddess) see "Pallas Athene NET, 2015) that the Greek wisdom goddess always carried a large snake (Greek "Puthon" or "Pytho"; Hebrew "Sophen") as a source of symbol of knowledge; Nnaji, 2013; OJPP: International Journal of Philosophy: Denver: SCRIP; NET).

11)Please see Acts 16:16, Greek "Puthonia” (English "Python”) Hebrew Ophensophiphon (Genesis 49:17, i.e. crafty-viper) a source of fortune telling; also called familiar spirit; Aramaic "Baalas-ob” (Hellenist-Hebrew, "Phalasoph", i.e. familiar spirit or witchcraft, i.e. Hebrew "cesephi”, Exodus 18:22 "A witch (cesophi) must die. Deuteronomy 18:9-14 "Losaphim" (i.e. consulting the dead. 1 Samuel 28:1-11 or Philosophim; Numbers 23:14, (Balaamsophim) i.e. he who consults the dead or the gods.

12)Very Important: that the oldest names for Egypt were KJV"Noph" (Naphuli, idolatry) (NIV is Memphis, deceit and idolatry) Jeremiah 46:19, Isaiah 19:13 KJV, then "Mizrain" in later years.

13)That Phoenician "Baalserphe” or "Blasepha" (English "Blasphemy") is Hebrew "Philasopha” i.e. to speak evil of God.

a) See Isaiah 27:11 "Baalsapha” or Genesis 11:7-9 “Balusapha” (see Revelations 9:11, Abad is Apol), which 
gives us the Hellenist Hebrew "Philasapha”, i.e. confused speech, divisive and senseless arguments; or b) Isaiah 27:9 "Philila" (senseless visions, or leaser without vision).

\section{References}

Aland, K., \& Newman, B. (1983). The Greek New Testament and Lexicon. Stuttgart: UBS.

Ali, Y. (1970). The Holy Quran English Translation. Pakistan: Curzon.

Boer, H. (1980). A Short History of the Early Church. Grand Rapids: Eerdsman.

Bromiley, G. (1985). Theological Dictionary of the New Testament (Abridged). Michigan-Grand Rapids: Eerdsman.

Brown, P., Driver, S., \& Briggs, C. i.e. BDB (2007). Hebrew-English Old Testament. Massachusetts: Hendrickson.

Brown, R., \& Comfort, P. (1990). The New Greek—English Interlinear New Testament. Illinois: Tyndale.

Goodnews, C. (2008) The Goodnews Catholic Bible. Lifton: American Bible Society and Collins.

Goodrich, E., \& John, K. (1990) Zondervan Exhaustive NIV Concordance. Grand Rapids: Eerdsman.

Hawkins, J. (1995). Oxford Mini-Referencing Dictionary of Current English. London: Oxford University Press.

Maier, P. (1988). An Illustrated Edition of Jewish Antiquities and the Jewish War Grand Rapids (pp. 1-267).

Mansoor, M. (2004). Step by Step Biblical Hebrew (Vol. 1). Grand Rapids, MI: Baker Academic.

McCain, D. (2005). New Testament Notes. Bukuru: ACTS.

Metzger, B. (2001). The Greek New Testament Lexicon (pp. 1-17, 69-78 etc.). Illinois: Baker.

New, C., \& Philips, C. (1953). Ancient World History to 1776. Ontario: Clarke and Dent.

Robinson, M., \& Davidson, G. (1996). Chambers Century Dictionary. London and Clarendon: Chambers.

Russell, T. F., \& Kyoungwon, C. (2006). Invitation to Biblical Hebrew: A Beginning Grammar. Grand Rapids: Kregel.

Simpson, J. A., \& Weiner, E. S. C. (1989). Oxford Encyclopedic Dictionary of Current English. Oxford: Clarendon Press.

Hebrew Old Testament (2005) London: SDHT.

The King James Version of the Holy Bible (1611). Revised 2011; London: Spottiswoode.

Wilson, A. (1965). Latin Dictionary. London: English Universities Press.

Woodrow, O. (1969). Babylon: The Mystery Religion. Washington DC: Evangelicals. 